\title{
THE AEROBIC CAPACITY AND MUSCLE STRENGTH ARE CORRELATED IN CANDIDATES FOR LIVER TRANSPLANTATION
}

\author{
Lucas Homercher GALANT ${ }^{1}$, Luiz Alberto FORGIARINI Jr. ${ }^{2}$ and Alexandre Simões DIAS ${ }^{3}$
}

\begin{abstract}
Liver diseases are responsible for metabolic and cardiorespiratory alterations. The objective of this paper is to correlate the maximal oxygen uptake $\left(\mathrm{VO}_{2 \max }\right)$ and respiratory muscle strength and evaluating the quality of life in liver transplant candidates. Cross-sectional study consisted of 26 patients with cirrhosis who underwent maximal exercise testing, respiratory muscle strength and SF-36. There was a correlation of $\mathrm{VO}_{2 \max }$ with MIP $(\mathrm{r}=0.61)$ and low scores of quality of life. A correlation of $\mathrm{VO}_{2 \max }$ to muscle strength and decreased quality of life in patients with liver disease.
\end{abstract}

HEADINGS - Liver transplantation. Respiratory muscles. Muscle strength.

\section{INTRODUCTION}

Advanced liver disease is responsible for metabolic abnormalities and malnutrition, as well as the loss of muscle mass in patients who have advanced liver disease. With that individuals experience changes in functionality and physical inactivity constant. The combination of these factors negatively influences aerobic capacity and activities of daily living, decreasing quality of life in this group of patients ${ }^{(3)}$.

Thus, the rate of maximal oxygen consumption measured by $\mathrm{VO}_{2 \max }$ can be decreased as a result of the processes of muscle dysfunction and cachexia, which will negatively influence on physical fitness and strength of respiratory muscles in individuals with chronic liver disease ${ }^{(2)}$.

This study aims to evaluate the quality of life and correlate the aerobic capacity $\left(\mathrm{VO}_{2 \max }\right)$ and respiratory muscle strength in patients with chronic liver disease who are in waiting list for the orthotopic liver transplantation.

\section{METHODS}

This is a cross-sectional study with convenience sample. The sample was 26 adult patients who were followed up with the Liver Transplant Service, Complexo Hospitalar, Santa Casa de Porto Alegre, RS, Brazil, from December 2009 to April 2010.
The study included all individuals who had medical conditions to carry out the proposed procedures. All patients were in clinical monitoring and periodic conditions had to perform the tests recommended, and presented no factors that interfere in the variables measured (non-cooperation, hemodynamic instability, limited mobility and neuromuscular disease).

Patients underwent a single moment the following assessment: data recording and the characteristics of the sample through an evaluation form specifically designed, assessing the strength of respiratory muscles through the manometer test and maximal oxygen uptake $\left(\mathrm{VO}_{2 \max }\right)$. The measurements were made by the same physiotherapist.

The term informed consent was obtained from each patient and the study was approved by the Ethics and Research of Methodist University - IPA, and the Complexo Hospitalar Santa Casa de Porto Alegre.

To measure the strength of respiratory muscles ( $\mathrm{cm} \mathrm{H}_{2} \mathrm{O}$ ) was used a digital manovacuometer MVD $500\left(\right.$ Globalmed $\left.^{\mathbb{}}\right)$, and for assessment of maximal inspiratory pressure (MIP), the individual was asked to undertake a maximal expiration to residual volume, and after proper positioning of equipment in the patient's mouth was made a forced inspiration to reach total lung capacity. To assess the maximal expiratory pressure (MEP) has been requested from the individual who began the maneuver from total lung capacity, which was followed by a maximal forced expiration. To carry out

\footnotetext{
Centro Universitário Metodista - IPA e Complexo Hospitalar Santa Casa - Serviço de Transplante Hepático, Porto Alegre, RS, Brasil.

1 Programa de Pós-graduação (Mestrado) em Hepatologia, Universidade Federal de Ciências da Saúde de Porto Alegre, RS; ${ }^{2}$ Programa de Pós-graduação (Doutorado) em Ciências Pneumológicas, Universidade Federal do Rio Grande do Sul, Porto Alegre, RS; ${ }^{3}$ Escola de Educação Física, Universidade Federal do Rio Grande do Sul, Porto Alegre, RS, Brasil.

Correspondence: Dr. Alexandre Simões Dias - Rua Hipólito da Costa, 543/casa 18 - Santa Teresa - 90840-110 - Porto Alegre, RS, Brasil. E-mail: simoesdias@terra.com.br
} 
the maneuvers, the equipment should be properly positioned on the patient's mouth to test failure does not exist.

The results were obtained after completion of five maneuvers, resulting in at least three acceptable, where the values did not differ by more than $10 \%$ of maximum. The normal values recommended by the Brazilian Society of Pulmonology was used. The quality of life in patients with chronic liver disease on the waiting list for liver transplantation was assessed using the quality of life questionnaire Short Form-36 (SF-36), which describes and evaluates the health status of individuals through multiple domains (physical functioning - SF-36, limited by physical aspects - SF-36, pain - SF- $36_{3}$, the general health status - SF-36 ; vitality - SF$36_{5}$; social aspects - SF-36; mental health - SF- $36_{7}$, limited by emotional aspects $-\mathrm{SF}-36_{8}$ ). The scores in each domain are obtained by adding the responses of that item, turning these raw scores on a scale where 0 represent poor health and 100 healthy states.

Cardiopulmonary exercise testing for measurement of $\mathrm{VO}_{2 \max }$ was obtained during exercise testing using maximum incremental protocol of Bruce. The protocol has five stages of 3 minutes each, where the slope and speed were increased in each stage, respectively, $2 \%$ and $0.85 \%$ miles $/ \mathrm{h}$ or $1.4 \mathrm{~km} / \mathrm{h}$. The test began with $10 \%$ slope and 1.7 miles $/ \mathrm{h}$ or $2.7 \mathrm{~km} / \mathrm{h}$.

The Borg scale for measuring the effort of individuals was used before and immediately after tests ${ }^{(5)}$.

Statistical analysis was performed using SPSS (Statistical Package for Social Sciences) version 16.0, and to verify the homogeneity of the sample was applied the Kolmogorov Smirnov. For correlations between variables was used Pearson correlation test. The level of significance was $P<0.05$.

\section{RESULTS}

The clinical and anthropometric sample are described in Table 1, and the 26 individuals who participated in the study had a mean MELD of $16 \pm 5$, and 8 patients diagnosed with alcoholic cirrhosis, 16 patients with hepatitis caused by hepatitis $C$ virus and 2 by hepatitis B.

To $\mathrm{VO}_{2 \max }$ correlate with MIP found a value of $\mathrm{r}=0.64$ $(P=0.001)$, and when the $\mathrm{VO}_{2 \max }$ correlated with the MELD value was $\mathrm{r}=0.91(P=0.001)$. In relation to areas of the SF-36 individuals pre-transplant showed low scores on all questionnaire scores, especially in areas relating to functional capacity, limited by physical appearance, pain, general health and vitality.

\section{DISCUSSION}

The study demonstrates a positive correlation between muscle strength and maximal oxygen uptake in patients waiting for liver transplantation. We found no findings in the literature citing association or relationship between these variables. However, such disorders are the consequence of pathological processes affecting the liver parenchyma, affecting mainly the mechanism of protein homeostasis, in which give rise to a physical ailment of individuals, negatively
TABLE 1. Anthropometric and clinical characteristics of individuals

\begin{tabular}{lc}
\hline Characteristics & $\mathrm{n}=26$ \\
\hline Age (years) & $52,57 \pm 8,51$ \\
Gender $-\mathrm{M} / \mathrm{F}$ & $14 / 12$ \\
IMC & $25,46 \pm 2,25$ \\
MELD & $16 \pm 5$ \\
Primary diagnosis $-\mathrm{n}$ & \\
$\quad$ Alcoholic cirrhosis & 8 \\
HCV cirrhosis & 16 \\
HBV cirrhosis & 2 \\
MIP & $72,92 \pm 21,50$ \\
MEP & $79,26 \pm 29,47$ \\
VO max $_{2}$ & $17,01 \pm 5,91$ \\
SF-36 & $47,46 \pm 25,76$ \\
SF-36 & $35,46 \pm 37,99$ \\
SF-36 & $49,11 \pm 23,67$ \\
SF-36 & $41,50 \pm 18,42$ \\
SF-36 & $47,80 \pm 28,44$ \\
SF-36 & $61,25 \pm 30,94$ \\
SF-36 & $51,04 \pm 42,14$ \\
SF-36 & $58,50 \pm 29,84$ \\
\hline
\end{tabular}

The age, weight, BMI, MIP, MEP, $\mathrm{VO}_{2 \max }$ and the scores of the SF- 36 are described as mean and standard deviation $( \pm) . \mathrm{M} / \mathrm{F}=$ male/female; $\mathrm{BMI}=$ body mass index; MELD - model for end liver disease; HCV - hepatitis caused by hepatitis $\mathrm{C}$ virus; HCB - caused by the hepatitis $\mathrm{B}$ virus; MIP - maximum inspiratory pressure $\left(\mathrm{cm} \mathrm{H}_{2} \mathrm{O}\right)$; $\mathrm{PE} \max =$ maximal expiratory pressure $\left(\mathrm{cm} \mathrm{H}_{2}\right)$ ); $\mathrm{VO}_{2}$ - maximal oxygen consumption $(\mathrm{mL} / \mathrm{min} / \mathrm{kg}) ; \mathrm{SF}-36$ = short form 36 SF-36 = functional ability, SF-36 = limitation of physical appearance, SF-36 $=$ pain: SF-36 $=$ general health, SF- $36_{5}=$ vitality, $\mathrm{SF}=$ social $-36_{6}, \mathrm{SF}-36_{7}=$ mental health, SF- $36_{8}=$ limitation by emotional aspects

affect the aerobic and muscular response ${ }^{(4)}$. The rate of adenosine triphosphate (ATP), phosphocreatine (PCr) and total magnesium $(\mathrm{Mg} 2+)$ is decreased in skeletal muscle of patients with cirrhosis, which would explain the reduction in peak $\mathrm{VO}_{2 \max }$ found in our study. The loss of muscle mass by this type of population may be caused by the decrease in mitochondrial oxidative capacity and/or the number of mitochondria in muscle tissue. This concept was demonstrated by Jacobsen et al. ${ }^{(4)}$ because the highest rates of mitochondrial ATP and PCr were submitted by individuals classified as Child Pugh A compared to patients who had scores B and C. The moment you realize the correlation between the $\mathrm{VO}_{2 \max }$ vs MELD, have demonstrated a strong inverse correlation between these two variables, confirming that the progression of liver disease has a negative impact on maximum oxygen consumption.

Barcelos et al.$^{(1)}$ evaluated the quality of life in patients before transplantation and found a reduction in the scores of the SF-36 compared with subjects who underwent liver transplantation. Our findings demonstrate that individuals who wait in the waiting list for allocation of grafts have reduced the scores of quality of life.

Finally, we demonstrate that this positive correlation between $\mathrm{VO}_{2 \max }$ and MIP and the inverse correlation between the MELD and $\mathrm{VO}_{2 \max }$ may negatively influence the quality of life of patients waiting on the waiting list for orthotopic transplantation liver. 
Galant LH, Forgiarini Jr LA, Dias AS. A capacidade aeróbica e a força muscular inspiratória estão correlacionadas em candidatos ao transplante hepático. Arq Gastroenterol. 2011;48(1):86-8.

RESUMO - As doenças hepáticas são responsáveis pelas alterações metabólicas e cardiorrespiratórias. O objetivo deste estudo foi correlacionar o consumo máximo de oxigênio $\left(\mathrm{VO}_{2 \max }\right)$ com a força muscular respiratória e avaliar a qualidade de vida em candidatos ao transplante de fígado. Trata-se de estudo transversal, composto por 26 pacientes com o diagnóstico de cirrose hepática que realizaram os testes de esforço máximo, força muscular respiratória e questionário SF-36. Observou-se correlação do $\mathrm{VO}_{2 \max }$ com a PIMáx $(r=0,61)$ e baixos escores de qualidade de vida. Houve correlação do $\mathrm{VO}_{2 \max }$ com força muscular inspiratória, bem como diminuição da qualidade de vida nos doentes hepáticos.

DESCRITORES - Transplante de fígado. Músculos respiratórios. Força muscular.

\section{REFERENCES}

1. Barcelos S, Dias AS, Forgiarini Jr LA. Monteiro MB. Transplante hepático: repercussões na capacidade pulmonar, condição funcional e qualidade de vida. Arq Gastroenterol. 2008:45:186-91.

2. Dharancy S, Lemyze M, Boleslawsky E, Neviere R, Declerck N, Canva V, Wallaert B, Mathurin P, Pruvot FR. Impact of impaired aerobic capacity on liver transplant candidates. Transplantation. 2008;86:1077-83.

3. Galant LH, Ferrari R, Forgiarini Jr, Monteiro MB, Marroni CA, Dias AS. Relationship between MELD severity score and the distance walked and respiratory muscle strength in candidates for liver transplantation. Transplant Proc. 2010;42:1729-30.
4. Jacobsen EB, Hamberg O, Quistorff B, Ott P. Reduced mitochondrial adenosine triphosphate synthesis in skeletal muscle in patients with Child-Pugh class B and C cirrhosis. Hepatology. 2001;34:7-12.

5. Schlant RC, Blomqvist CG, Brandenburg RO, DeBusk R, Ellestad MH Fletcher GF, Froelicher VF Jr, Hall RJ, McCallister BD, McHenry PL, et al. Guidelines for exercise testing. A report of the Joint American College of Cardiology / American Heart Association Task Force on Assessment of Cardiovascular Procedures (Subcommittee on Exercise Testing). Circulation. 1986;74:653a-67a 